\title{
The Integration of a Lesson Study Model into Distance STEM Education during the COVID-19 Pandemic: Teachers' Views and Practice
}

\author{
Ahmet Aykan ${ }^{1} \cdot$ Bekir Yıldırım $^{2}$ (D) \\ Accepted: 19 August 2021 / Published online: 29 August 2021 \\ (c) The Author(s), under exclusive licence to Springer Nature B.V. 2021
}

\begin{abstract}
This paper investigated the integration of a Lesson Study Model (LSM) into distance STEM education during the COVID-19 pandemic. The study focused on six dimensions: (1) STEM education in distance learning, (2) Lesson Study (LS), (3) lesson planning processes, (4) challenges of lesson planning, (5) evaluation and assessment methods, and (6) strategies, methods, and techniques. The sample consisted of 24 science teachers recruited using criterion sampling, which is a purposive sampling method. A case study, which is a qualitative research method, was the design of choice. Data were collected through interviews, videotapes, and expert observations. The data were analyzed using inductive content analysis. Themes, categories, and codes were developed in accordance with the research purpose. Participants had positive opinions about the LSM, STEM education, and distance learning. Participants stated that the LSM activities within distance learning contributed to pedagogy and content knowledge in the STEM education process. The challenges faced by participants were unfavorable environmental conditions, time management issues, and a lack of knowledge and experience in lesson planning. Expert observations and videotapes corroborate these results, indicating that the LSM integrated with STEM education results in higher quality STEM lesson planning and teaching. Moreover, distance learning platforms are promising ways to ensure the professional development of teachers during the pandemic.
\end{abstract}

Keywords STEM education · Lesson study model · Teacher · Lesson plan · Distance learning

Bekir Yıldırım

bekir58bekir@gmail.com

1 Department of Education Science, Faculty of Education, Mus Alparslan University, 49250 Mus, Turkey

2 Department of Mathematics and Science Education, Faculty of Education, Mus Alparslan University, 49250 Mus, Turkey 


\section{Introduction}

Advances in information and communication technology (ICT) have changed how we view education. This new perspective has paved the way for changes in educational institutions and the integration of ICT into education (Turan et al., 2013). Moreover, the COVID-19 pandemic has accelerated the integration of ICT into educational environments. These developments have also had ramifications on professional development, which has become harder to achieve since the pandemic due to the lack of face-to-face learning. Therefore, we need to design flexible, affordable, and quality distance learning programs to help teachers develop professional skills during the pandemic (Powell \& Bodur, 2019). There are some concerns about distance learning (Parson et al., 2019), but well-planned distance learning can yield effective results for teachers (Darling-Hammond et al., 2017; Powell \& Bodur, 2019). Therefore, we need flexible, easy-to-access, collaborative, and multidisciplinary distance learning environments to meet teachers' professional needs. Researchers have recently focused on strategies to help teachers improve themselves professionally (Sadler et al., 2020). However, those strategies are far from perfect, preventing teachers from realizing themselves in the professional sense. Therefore, we should concentrate on distance learning processes to overcome those challenges.

We provided teachers with an LSM-based professional development program to help them develop high-quality STEM lesson plans for distance learning and then investigated what they thought of the program. In other words, we presented the program to teachers to improve their lesson planning skills and overall professional competence and then discussed their views of the model. We consider this study important because it will help teachers develop professional skills and better lesson plans. Another original aspect of this study is that it aimed to assist teachers in developing STEM education skills based on distance learning during the pandemic. Some studies discuss what teachers and preservice teachers think about STEM education (Arslan \& Yildırım, 2020; Karakaya et al., 2018; Margot \& Kettler, 2019; Park et al., 2017; Wang et al., 2011). Many other studies focus on lesson planning based on LSMs (Angelini \& Alvarez, 2018; Aykan, 2019; Fernandez, 2010; Lamb, 2015; Lyding, 2012; Skott \& Moller, 2017). However, those studies deal with STEM education and LSMs separately. This is the first study to integrate an LSM into STEM education and develop a program (LSM + STEM) in which teachers plan lessons, brainstorm about them, and then revise them. We then interviewed them to gain insight into their views of the program in order to evaluate the effectiveness of distance learningbased STEM education, LSM activities, and lesson planning processes. We also looked into what challenges teachers faced, what evaluation and assessment methods they used, and what strategies, methods, and techniques they implemented. The main research question was, "What do teachers think about the LSM program integrated into distance learning-based STEM education?" The study also sought answers to the following subquestions:

(1) What do teachers think about distance learning?

(2) What do teachers think about the LSM + STEM program?

(3) What are the implications of the LSM + STEM program on lesson planning processes?

(4) What are the implications of the LSM + STEM program on professional development?

(5) What are the implications of the LSM + STEM program on STEM teaching?

(6) What do experts think about lesson planning based on the LSM+STEM program? 
(7) What do videotapes tell us about lesson planning based on the LSM + STEM program?

\section{Literature Review}

\subsection{Distance Learning and Professional Development}

More than 200 countries have implemented drastic changes in their education systems since the onset of the pandemic. Novel Coronavirus disease (COVID-19) broke out in Wuhan, China, at the end of 2019 and has taken hold of the whole world since then. This global shock has forced countries to focus on alternative educational strategies (Sintema, 2020). The pandemic has caused a sudden shift from conventional classroom teaching to distance learning, leaving teachers face to face with numerous challenges that they had never experienced before. Distance learning has become so popular among all educational institutions that it has started to affect the professional development processes that teachers go through. Teachers interested in developing professional skills have turned to distance learning programs (Sadler et al., 2020). One of those programs is Lesson Study (LS), a Japanese educational practice model. LSM-based face-to-face learning has been replaced by distance learning since the onset of the pandemic (Huang et al., 2021).

\subsection{STEM Education}

STEM education incorporates the fields of science (S), technology (T), engineering (E), and mathematics (M) and relates them to daily life. Some countries (UK, USA, Turkey, etc.) have integrated STEM into formal and informal education to improve science and math literacy, teach 21st-century skills, and facilitate collaboration between schools and industries (Kim, 2019). Teachers are vital to education, and therefore, responsible for putting STEM education into practice (Timur \& İnançl1, 2018; Türk et al., 2018; Yıldırım, 2021). Teachers who can apply STEM education are more likely to have students with high academic performance. However, this also means that only those with a sound grasp of STEM education can integrate it into their lectures (Pang \& Good, 2000). Teachers with little knowledge of STEM fields are more likely to have negative attitudes towards them (Jamil et al., 2018). For example, preschool teachers with low self-perceived competence have more difficulty teaching science and math (Timur, 2012). Therefore, teachers should first develop competence before trying to incorporate STEM education into formal and informal education. Teachers' STEM education performance depends mostly on their strategies and methods (Okur Akçay, 2015) because the more effective the strategies and methods, the more likely it is that students can learn. Lesson planning turns STEM education from an abstract concept into a practical and applicable model. Lesson plans help teachers deliver class and perform in-class activities systematically (Kablan, 2012). Therefore, teachers interested in putting STEM education into practice systematically should prepare lesson plans.

\subsection{Lesson Study}

Countries put great effort into making teacher training effective (Aykan, 2019). Lesson Study (LS) is a professional development model that has been popular in recent years. It 
provides teachers with the opportunity to develop professional skills (Dudley, 2015; Saito $\&$ Atencio, 2013). American and European researchers have a growing interest in the education systems of Singapore, China, South Korea, and Japan because those countries successfully implement LS to improve academic performance, especially in PISA (Programme for International Student Assessment) and TIMMS (Trends in International Mathematics and Science Study) exams (Dudley, 2013; Fujii, 2014; Lewis, 2002; Norwich \& Ylonen, 2013). Lesson Study, which is a literal translation of "jugyo kenkyu," is a Japanese model of teaching improvement process (Tan, 2014) that consists of three steps: (1) teachers plan a lesson together, and one of them put it into practice, (2) other teachers observe it and take notes, and (3) they all come together again and revise the lesson plan (Lewis, 2009; Lewis et al., 2011). Lesson Study promotes collaboration, helping teachers develop skills and plan lessons better (Cheng \& Yee, 2012; Fernandez, 2010).

Equipped teachers and practical lesson plans have positive repercussions on teaching activities. In Japan, Lesson Study is mainly used for the professional development of math and science teachers. Lesson Study provides an opportunity for collaborative professional development through which teachers can analyze science course content and formulate new strategies (Baricaua Gutierez, 2016). Therefore, STEM teachers should be offered a Lesson Study Model (LSM) to allow them to collaborate and share their knowledge and experience, resulting in better lesson plans and more equipped teachers.

\section{Method}

\subsection{Design}

This paper adopted a case study research design to conduct an objective, valid, and reliable analysis of the impacts of the LSM on STEM education during distance learning. A case study is a qualitative research design used to understand and interpret a phenomenon in its natural setting (Merriam, 2009). We aimed to explore what teachers thought about the implications of the LSM on STEM education during distance learning. Our goal was to approach the topic from a holistic perspective. Therefore, we regarded each participant as a case.

\subsection{Participants}

Participants were recruited using criteria sampling, which is a non-probability purposive sampling method. Criteria sampling involves the selection of a sample that meets a predetermined set of criteria (Yıldırım \& Şimşek, 2011). It is a time- and cost-efficient method by which researchers select participants most suited to the research purpose (Patton, 2002). We selected science teachers who enrolled in distance learning and interviewed them after the LSM+STEM program. The inclusion criteria were as follows: (1) having completed distance learning, (2) planning lessons based on the program, (3) using the lesson plans in their lectures, and (4) volunteering. The sample consisted of 24 science teachers (19 women and five men) who met the inclusion criteria. Twenty participants had 1-10 years of experience, while the remaining had 11-20 years of experience. Participants were assigned pseudonyms (Ali, Aybüke, etc.) to assure anonymity. 


\subsection{Instruments}

\subsubsection{Teacher Interview Questionnaire}

Semi-structured interviews were conducted to determine participants' views of distance learning, STEM education, lesson planning, and the LSM. Participants were interviewed using the Teacher Interview questionnaire (TIQ) developed by the researchers. The questionnaire consisted of eight easy-to-understand and open-ended questions. The questionnaire was sent to two experts, one of whom had a Ph.D. degree and research on STEM education, while the other had a Ph.D. degree in educational programs and teaching and research on LS. The questionnaire was revised based on their feedback. A pilot study was conducted with three teachers to determine the intelligibility of the items. The questionnaire was completed based on their feedback (Appendix 1).

\subsubsection{Videotapes}

To corroborate the interviews and expert opinions, we video-recorded (a total of $24 \mathrm{~h}$ ) participants put their lesson plans into practice during distance learning. The videos were supported by participants' views and experts' observations.

\subsubsection{Lesson Plans}

Participants' lesson plans based on the cyclical process of the LSM were used to assess their STEM teaching. The lesson plans were analyzed to look into the implications of the LSM on STEM teaching and were also used to corroborate the qualitative data and evaluate STEM teaching performed by participants. They were examined based on the criteria in Table 1 .

Table 1 Evaluation criteria for lesson plans

\begin{tabular}{|c|c|c|}
\hline & Criterion & Subcriteria \\
\hline 1 & Professional Skill & $\begin{array}{l}\text { Planning education } \\
\text { Creating learning environments } \\
\text { Managing the learning process } \\
\text { Evaluation and assessment }\end{array}$ \\
\hline 2 & STEM Integration & $\begin{array}{l}\text { Content knowledge } \\
\text { Integrating disciplines } \\
\text { Connecting with everyday life } \\
\text { Level-appropriateness }\end{array}$ \\
\hline 3 & 21 st-century skills & $\begin{array}{l}\text { Effective communication } \\
\text { Critical thinking } \\
\text { Empathizing } \\
\text { Collaboration } \\
\text { Problem-solving } \\
\text { Creativity }\end{array}$ \\
\hline 4 & Attitudes and Values & $\begin{array}{l}\text { Democratic attitude } \\
\text { Respect }\end{array}$ \\
\hline
\end{tabular}




\subsubsection{Observation}

Observation is a research method used to explore a group of people's attitudes and behaviors towards an event or phenomenon in any or regulated setting or to recognize the formal dimension of a topic of interest (Baltac1, 2019). Observation improves the validity and corroborates interview results (Baxter \& Jack, 2008). This study involved observations in enhancing the validity and checking whether different types of qualitative data confirmed each other. Two experts with a Ph.D. in LS made the observations based on predetermined criteria. The observations were based on the evaluation criteria for lesson plans (Table 1).

\subsection{Data Analysis}

Qualitative data were collected online through interviews. Each interview took 15-21 min (432 in total) and was recorded. The interviews were transcribed and then analyzed using content analysis. The content analysis was based on the five phases proposed by Kuckartz (2014). Two experts (one of whom had a Ph.D. degree and research on STEM education, while the other had a Ph.D. degree in educational programs and teaching and research on LS) developed themes, categories, and codes based on the content analysis results. They identified the parts on which they disagreed and discussed them until they reached a consensus. This process ensured intercoder reliability (Miles et al., 2014), which was $84 \%$. The intercoder agreement should be at least $80 \%$ (Patton, 2002). Therefore, the resulting agreement was adequate.

Permission was obtained from participants to videotape the interviews. Two experts analyzed the interviews. They identified the parts on which they disagreed and discussed them until they reached a consensus. This process ensured intercoder reliability regarding video analysis (Miles et al., 2014). The intercoder reliability was $80 \%$, which was adequate (Patton, 2002).

The lesson plans were analyzed based on the evaluation criteria (Table 1). The experts identified the codes on which they disagreed and discussed them until they reached a consensus. This process ensured intercoder reliability regarding the analysis of the lesson plans (Miles et al., 2014). The intercoder reliability was $84 \%$, which was adequate (Patton, 2002).

\subsection{Procedure}

This study was conducted with science teachers who attended distance learning for $59 \mathrm{~h}$. The objective of the training was to help them use the LSM to develop STEM lesson plans. Table 2 shows the training and data collection process.

\subsection{Results}

The themes, categories, and codes were presented in tables. Direct quotations were used to provide a coherent picture of participants' views and allow readers to interpret the findings. 


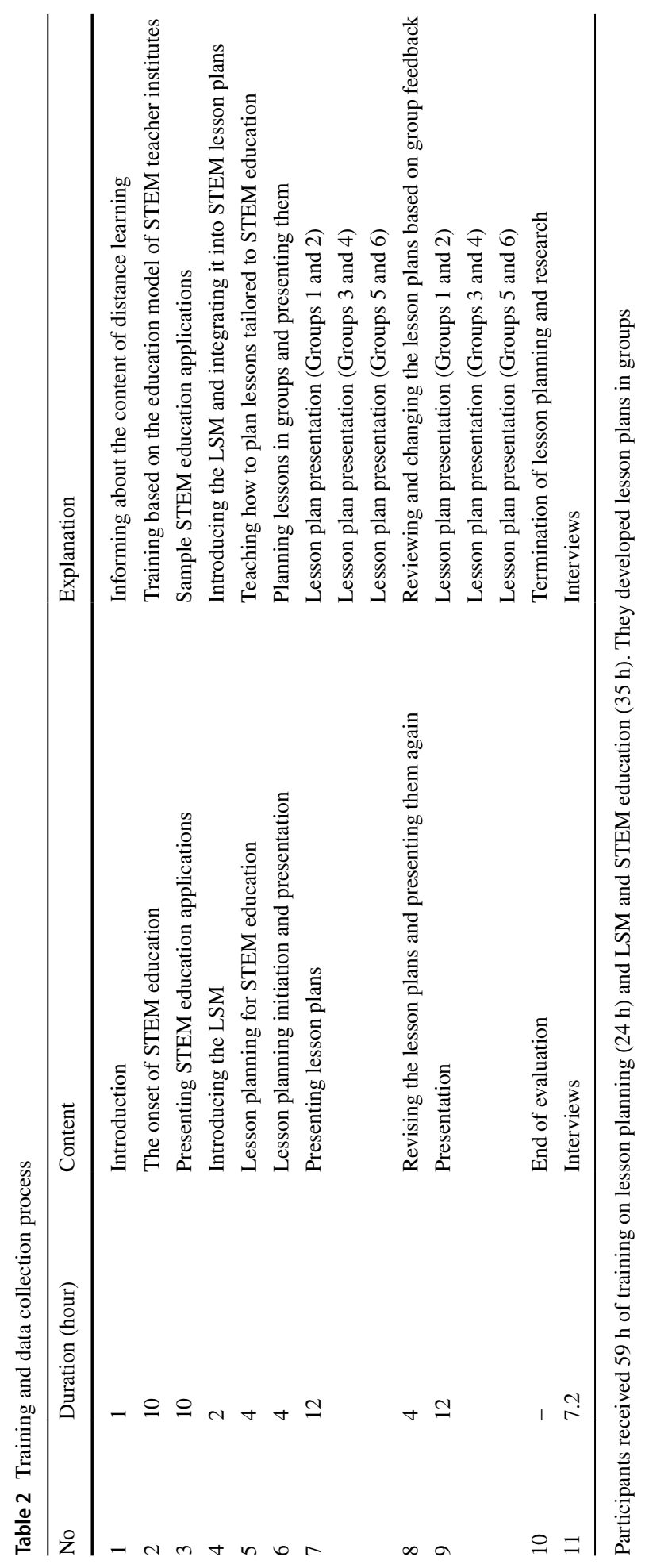




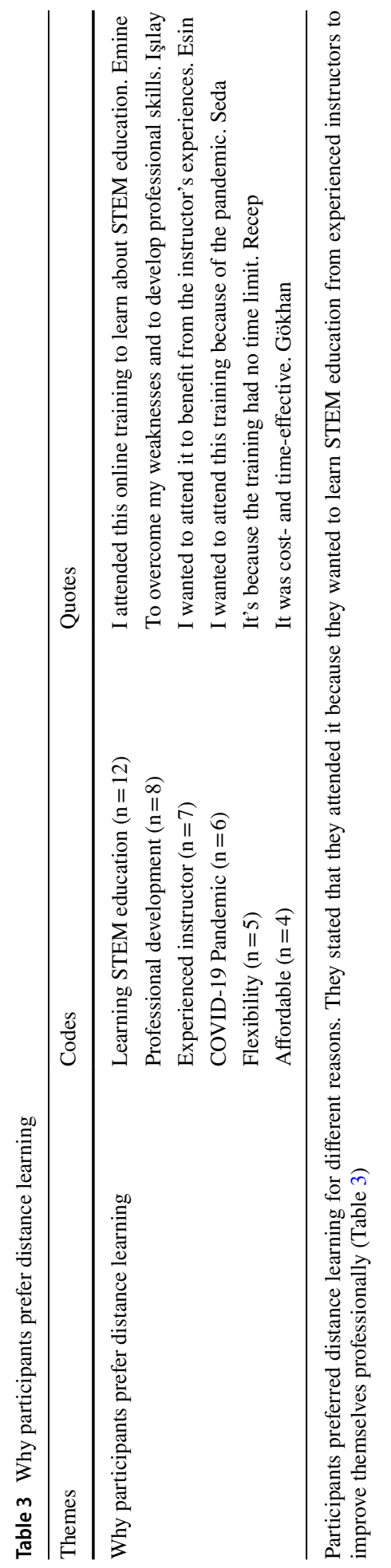




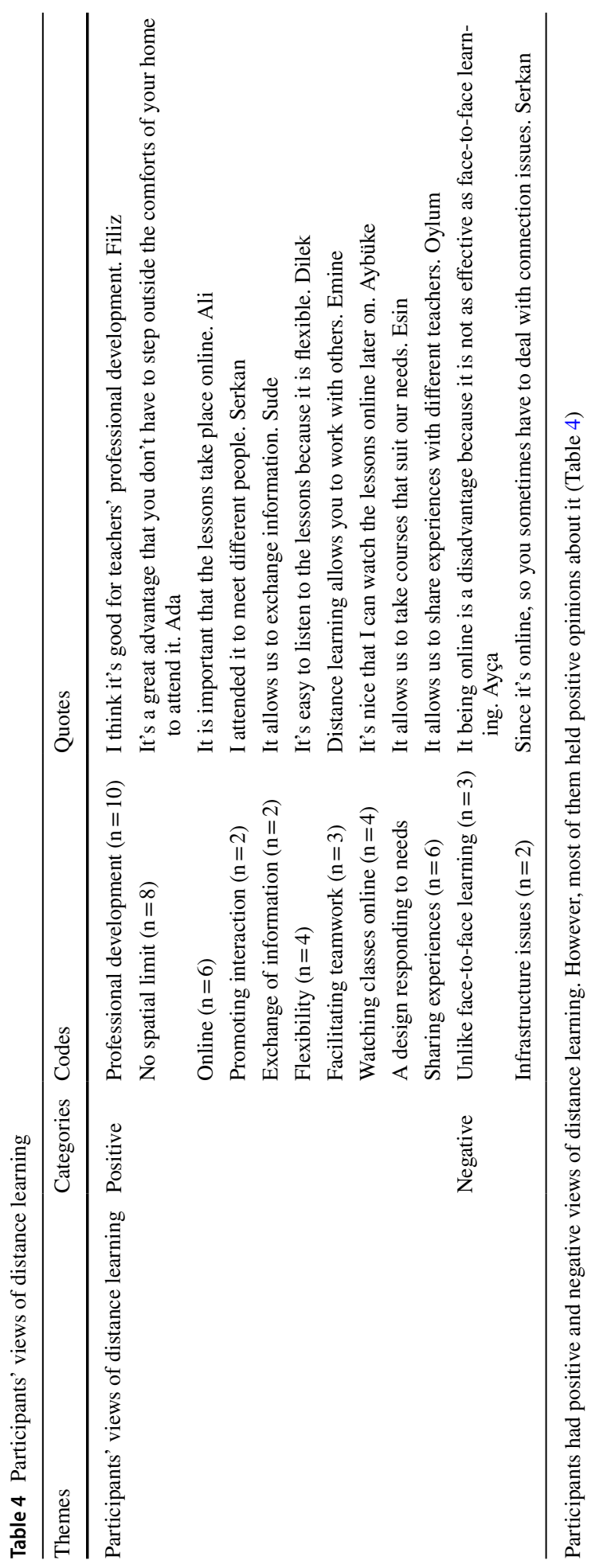




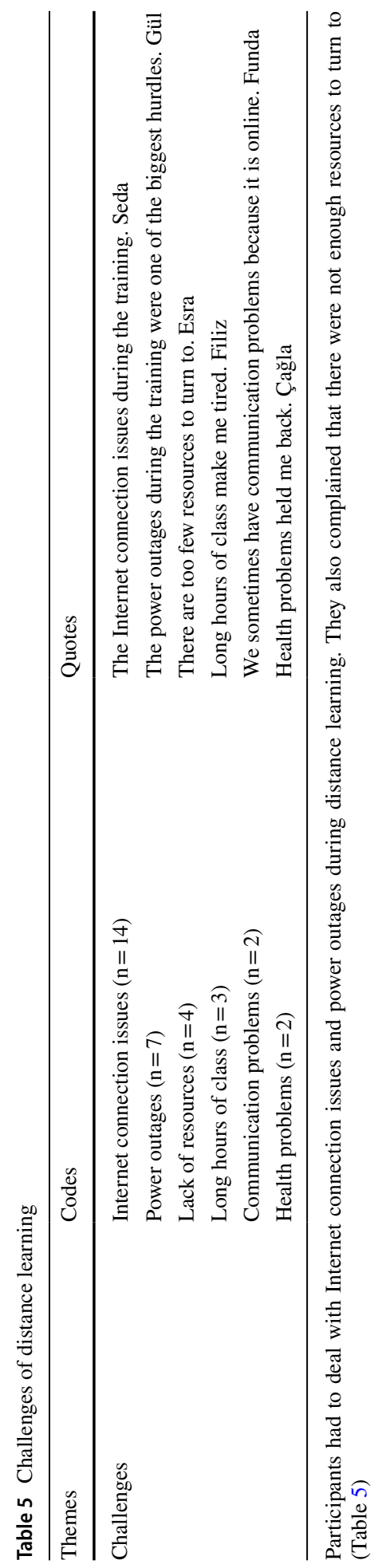




\subsection{Participants' Views of Distance learning}

The first subquestion investigated participants' views of distance learning (Tables 3, 4, 5).

\subsection{Participants' Views of the Lesson Study Model and STEM Education}

The second subquestion addressed participants' views of the LSM (Table 6).

\subsection{Participants' Views of STEM Education}

The second question of the second subquestion looked into what participants thought about STEM education within the scope of distance learning (Table 7).

\subsection{Contribution of Lesson Study to STEM Education}

The third question of the second subquestion focused on participants' views of the contribution of the LSM to STEM education (Table 8).

\subsection{The Effect of Lesson Study on STEM Lesson Planning}

The first question of the third subquestion investigated participants' views of the effect of the LSM on STEM lesson planning (Table 9).

\subsection{Challenges of Lesson Planning}

The second question of the third subquestion focused on what challenges participants faced when planning STEM lessons (Table 10)

\subsection{The Effect of the Lesson Study Model on Professional Development}

The first question of the sixth subquestion addressed how participants thought the LSM affected their professional development.

\subsection{The Effect of the Lesson Study Model on Pedagogical and Content Knowledge}

The first question of the fourth subquestion investigated how participants thought the LSM affected their pedagogical and content knowledge (Table 11). 


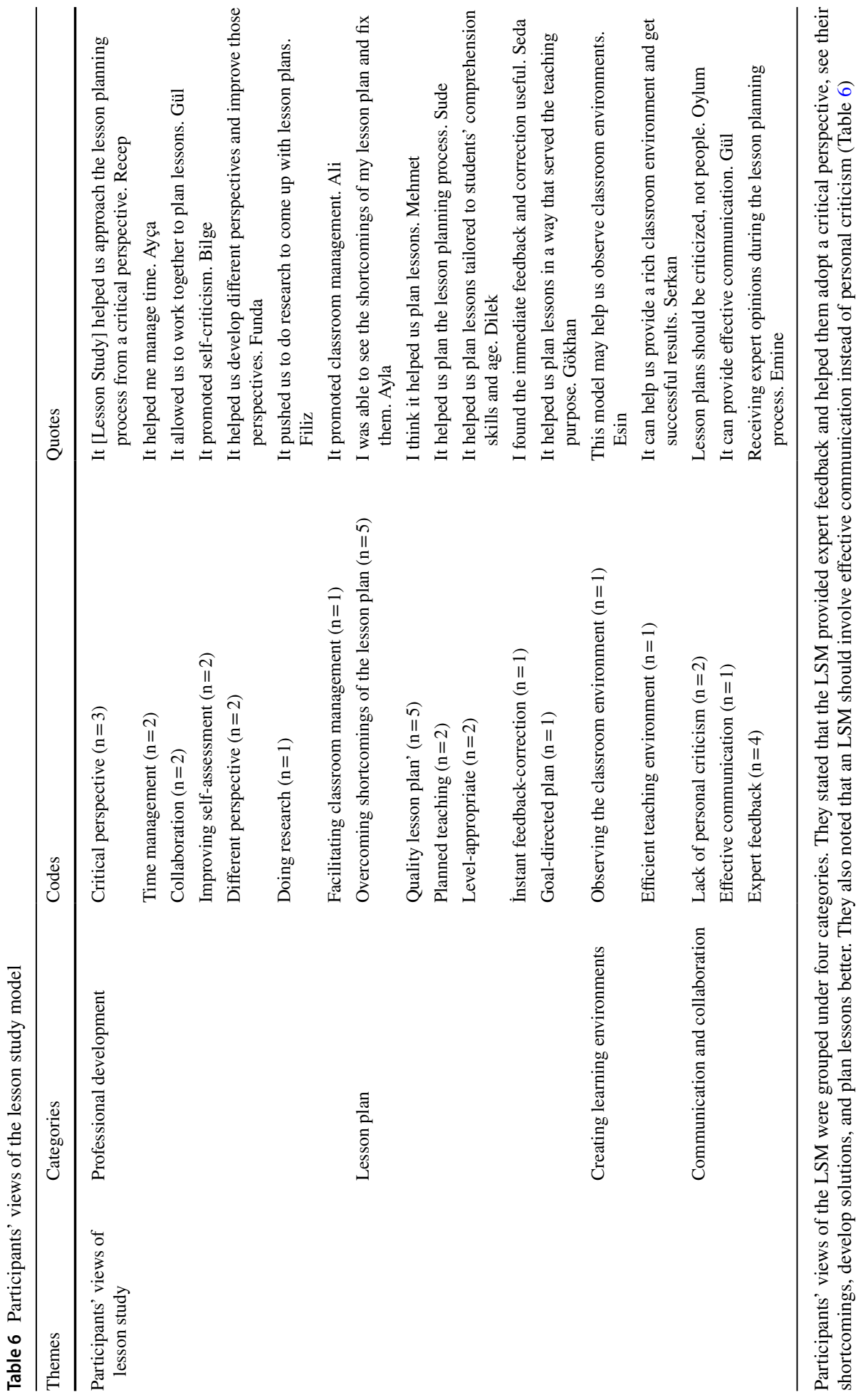




\subsection{Target LSM Skills}

The second question of the fourth subquestion focused on participants' views of target LSM skills (Table 12).

\subsection{The Impact of the LSM on STEM teaching}

Within the scope of the fifth subquestion, the lesson plans were taken into account to look into the impact of the LSM on STEM teaching. The lesson plans were analyzed according to the criteria given in Table 1 (Tables 13, 14).

\subsection{Expert Observation}

The sixth subquestion analyzed the experts' observations of the presentation of the lesson plans. Table 15 shows the expert observations.

\subsection{Experts' Views of Videotapes}

The seventh subquestion concentrated on experts' observations concerning the videotapes. Table 16 shows the experts' views of the videotapes.

\section{Discussion and Conclusion}

This study focused on the effect of a Study Lesson Model (LSM) on teachers' lesson plans tailored to STEM education. We analyzed participants' views under subquestions and reached the following conclusions:

The first subquestion addressed participants' views of distance learning. They reported some pros and cons of distance learning. As for pros, they stated that distance learning promoted professional development and allowed them to share information online whenever and wherever they wanted. They also noted that they preferred distance learning because they wanted to learn about STEM education and have related experiences to improve themselves professionally. Burns (2011) maintains that distance learning helps teachers develop professional skills. DeNeui and Dodge (2006) also stress that the greatest advantage of distance learning is that it allows students to participate in their learning whenever and wherever they want to. As for cons, our participants stated that they sometimes had to deal with power shortages and Internet connection problems. They also had difficulty accessing different sources. DePaepe et al. (2018) also claim that the lack of resources is one of the major challenges of distance learning. Our results are consistent with the literature (Horspol \& Lange, 2012; Chao et al., 2006).

The second subquestion looked into what participants thought about the LSM in distance learning. They stated that the LSM contributed to their professional development. This result is consistent with the literature (Aykan, 2019; Barber, 2018; Dudley, 2015; González \& Deal, 2017; Mitchell, 2017). For example, Chong and Kong (2012) and 


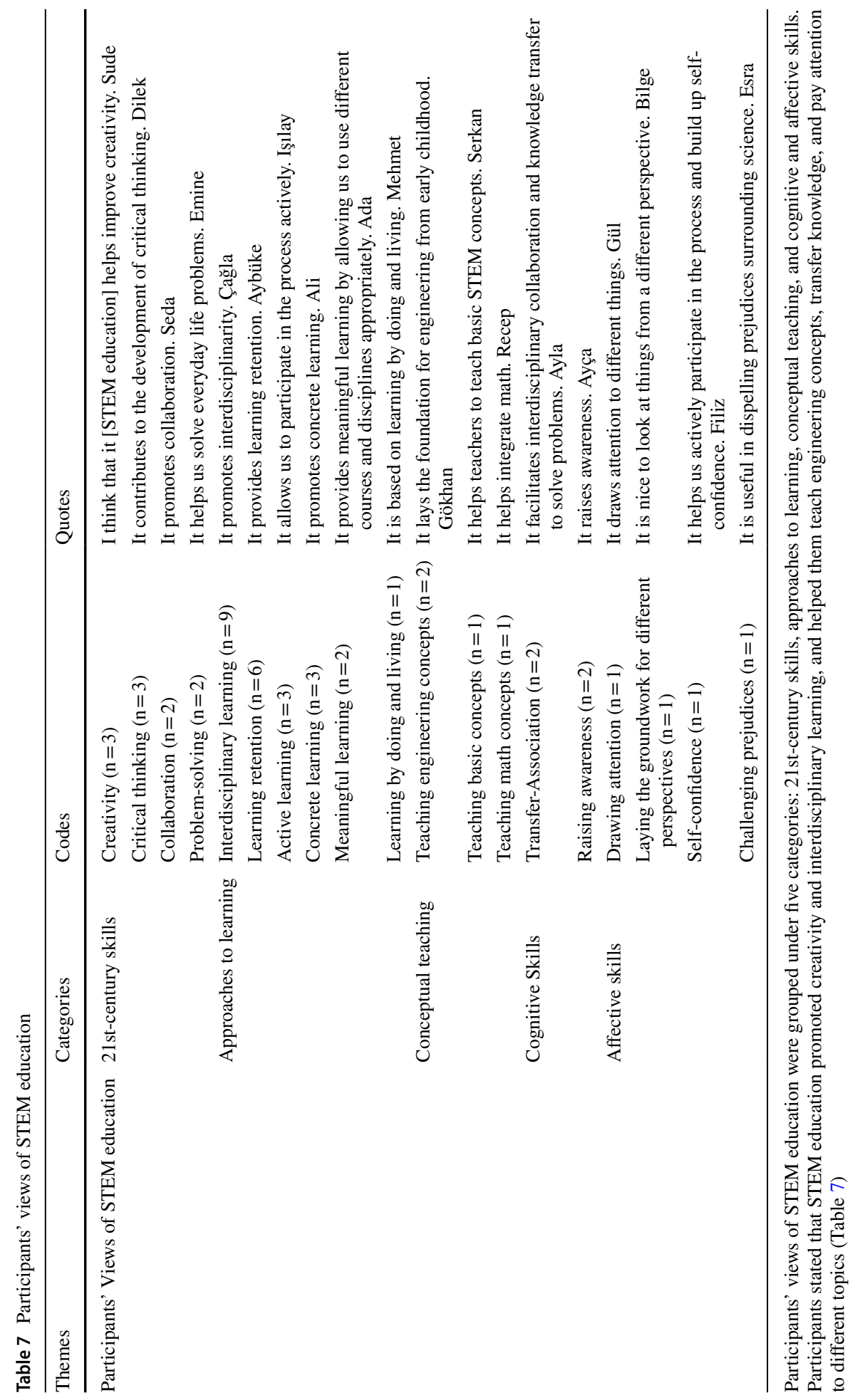




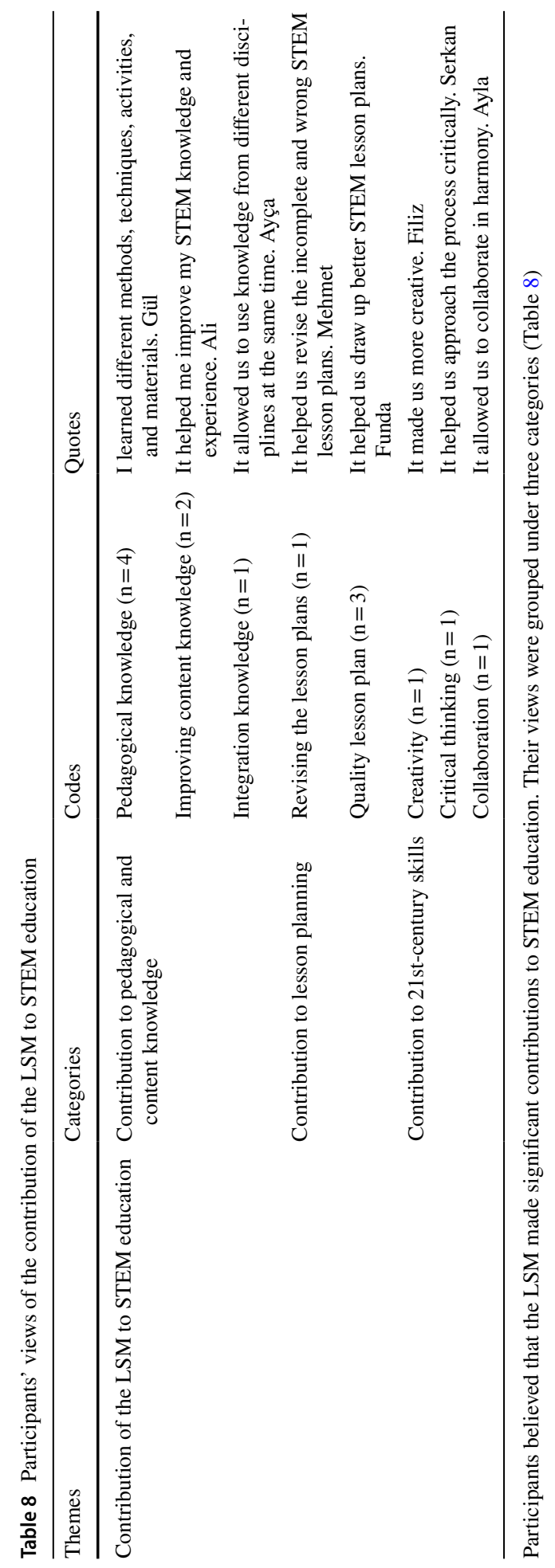




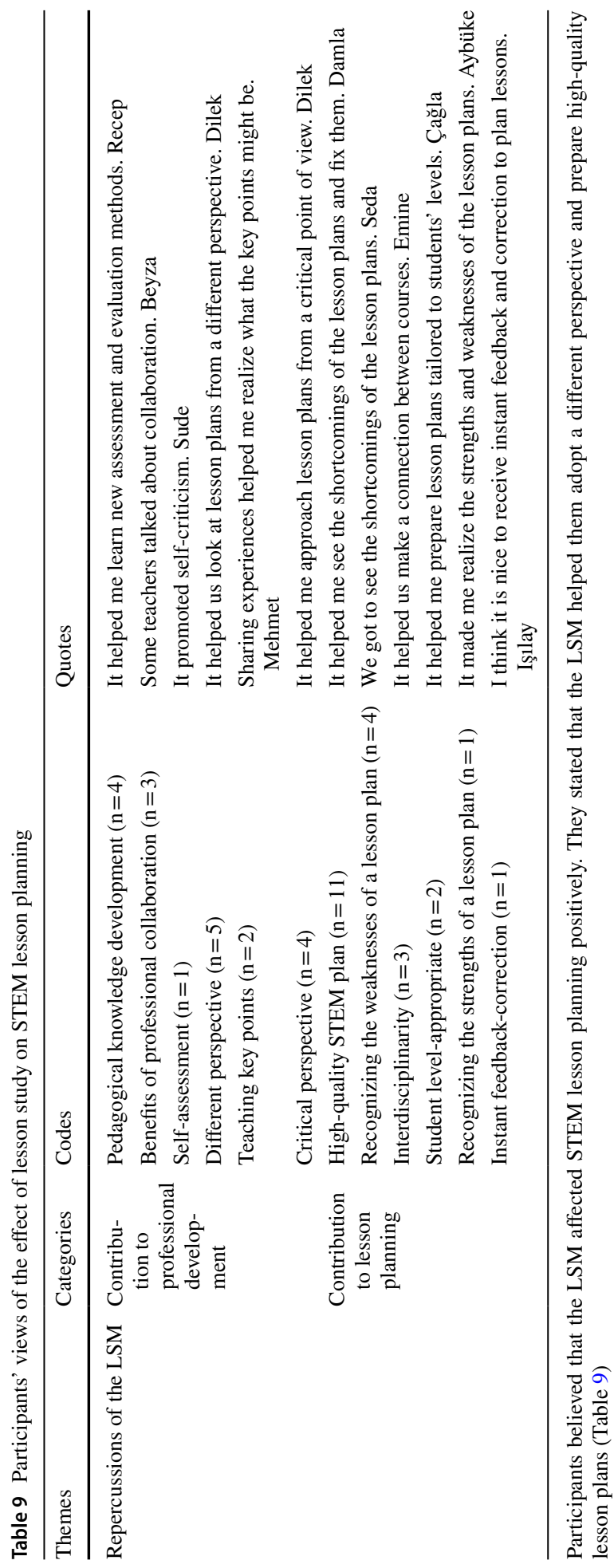




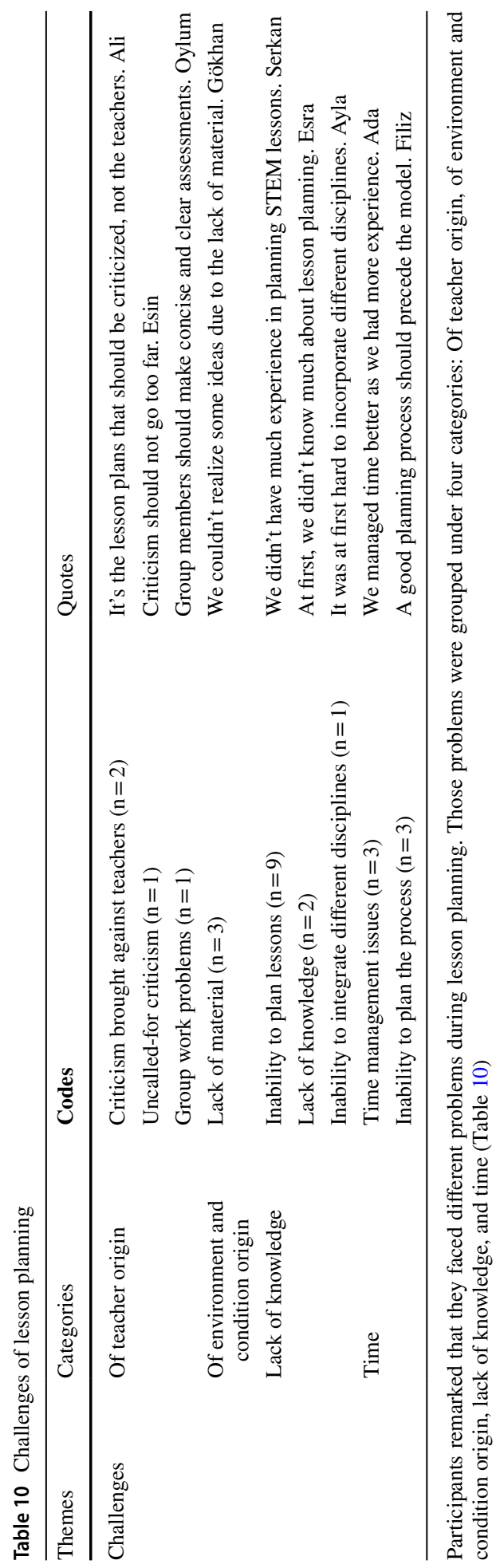




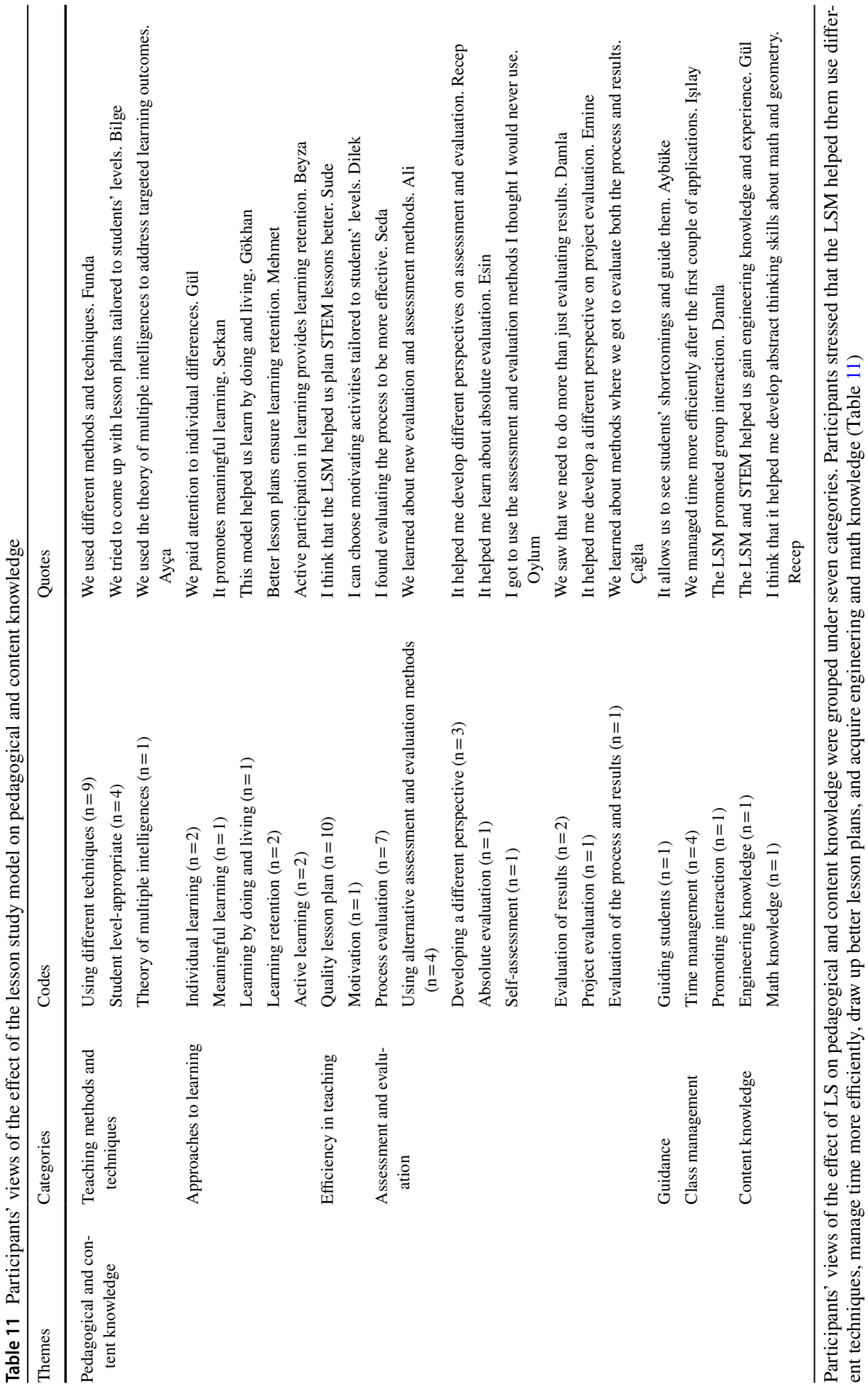




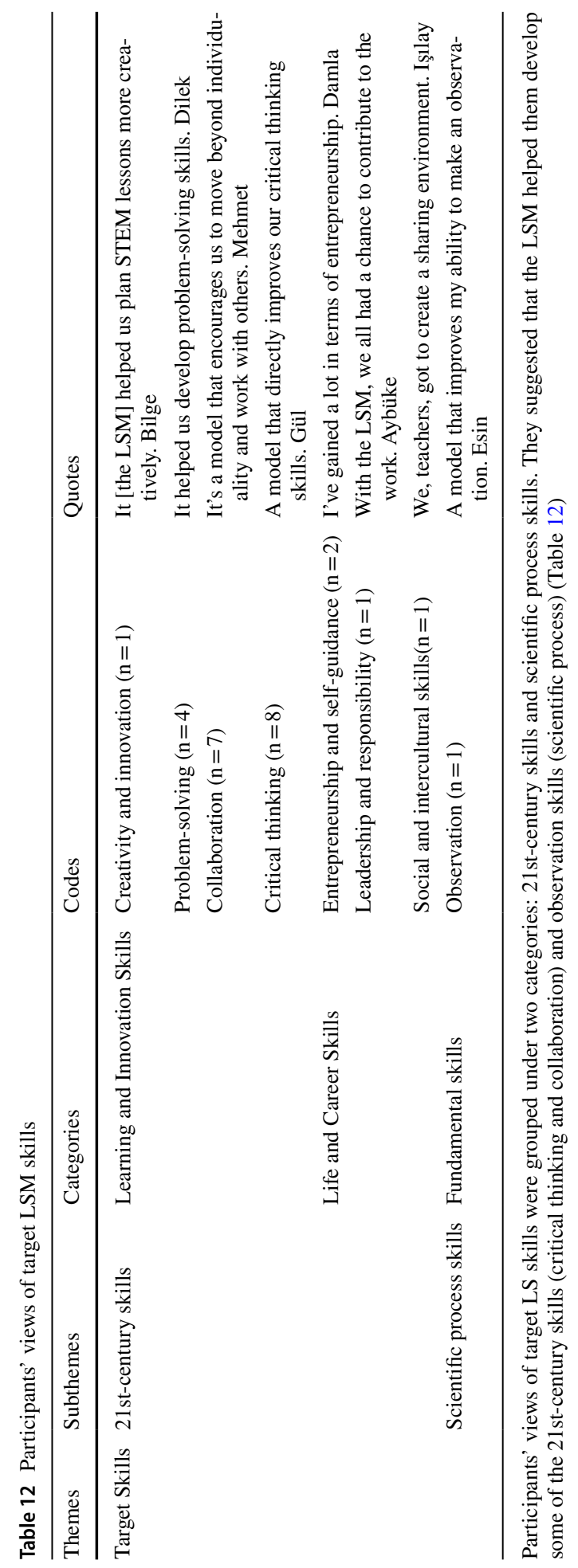




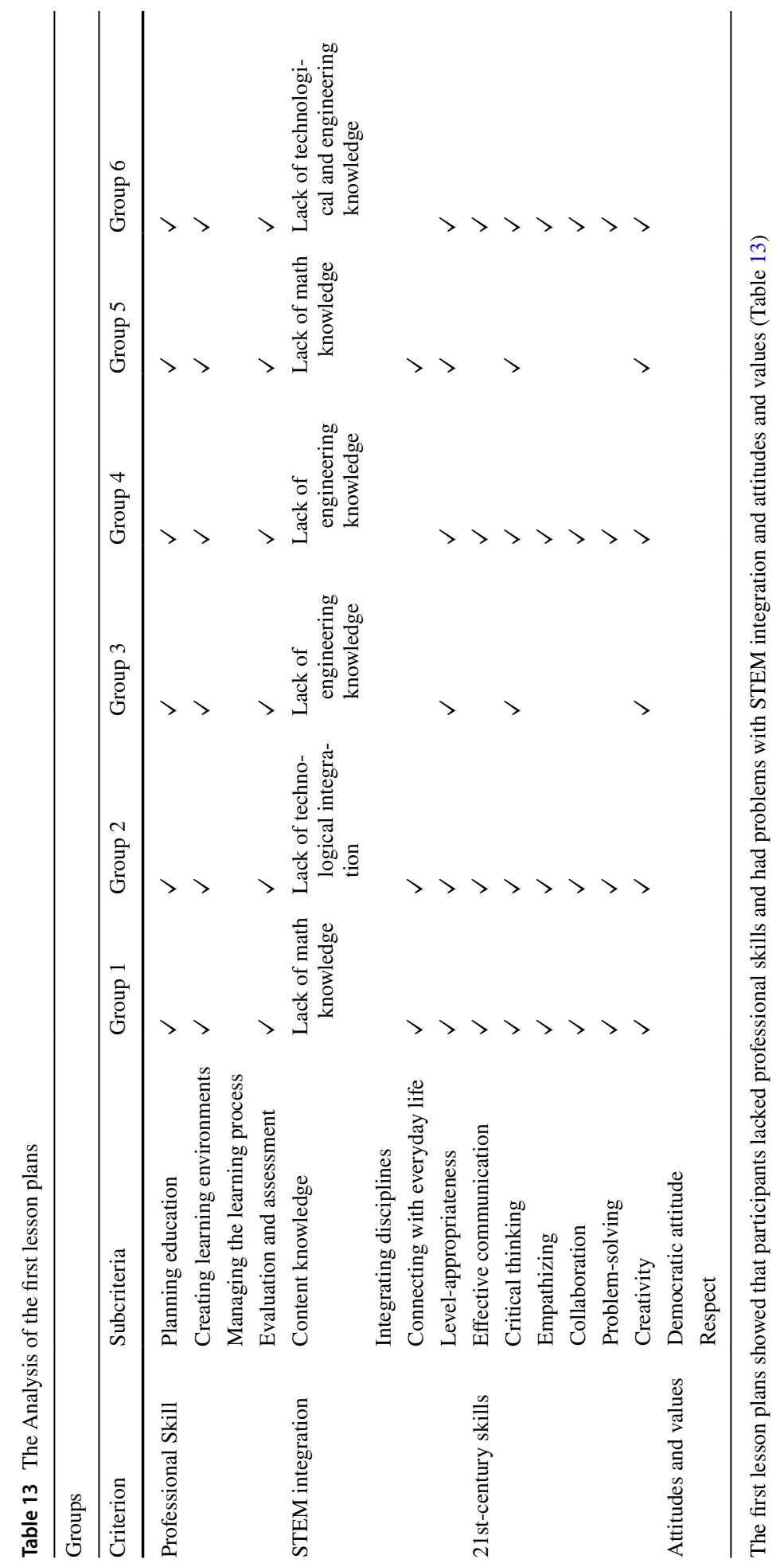


Table 14 The Analysis of the second lesson plans

\begin{tabular}{|c|c|c|c|c|c|c|c|}
\hline \multicolumn{8}{|l|}{ Groups } \\
\hline Criterion & Subcriteria & Group 1 & Group 2 & Group 3 & Group 4 & Group 5 & Group 6 \\
\hline \multirow{4}{*}{ Professional skill } & Planning education & $\checkmark$ & $\checkmark$ & $\checkmark$ & $\checkmark$ & $\checkmark$ & $\checkmark$ \\
\hline & $\begin{array}{l}\text { Creating learning envi- } \\
\text { ronments }\end{array}$ & $\checkmark$ & $\checkmark$ & $\checkmark$ & $\checkmark$ & $\checkmark$ & $\checkmark$ \\
\hline & $\begin{array}{l}\text { Managing the learning } \\
\text { process }\end{array}$ & $\checkmark$ & $\checkmark$ & $\checkmark$ & $\checkmark$ & $\checkmark$ & $\checkmark$ \\
\hline & $\begin{array}{l}\text { Evaluation and assess- } \\
\text { ment }\end{array}$ & $\checkmark$ & $\checkmark$ & $\checkmark$ & $\checkmark$ & $\checkmark$ & $\checkmark$ \\
\hline \multirow[t]{4}{*}{ STEM integration } & Content knowledge & $\checkmark$ & $\checkmark$ & $\checkmark$ & $\checkmark$ & $\checkmark$ & $\checkmark$ \\
\hline & Integrating disciplines & $\checkmark$ & $\checkmark$ & $\checkmark$ & $\checkmark$ & $\checkmark$ & $\checkmark$ \\
\hline & $\begin{array}{l}\text { Connecting with every- } \\
\text { day life }\end{array}$ & $\checkmark$ & $\checkmark$ & $\checkmark$ & $\checkmark$ & $\checkmark$ & $\checkmark$ \\
\hline & Level-appropriateness & $\checkmark$ & $\checkmark$ & $\checkmark$ & $\checkmark$ & $\checkmark$ & $\checkmark$ \\
\hline \multirow[t]{6}{*}{21 st-century skills } & $\begin{array}{l}\text { Effective communica- } \\
\text { tion }\end{array}$ & $\checkmark$ & $\checkmark$ & & $\checkmark$ & $\checkmark$ & $\checkmark$ \\
\hline & Critical thinking & $\checkmark$ & $\checkmark$ & $\checkmark$ & $\checkmark$ & $\checkmark$ & $\checkmark$ \\
\hline & Empathizing & $\checkmark$ & $\checkmark$ & & $\checkmark$ & $\checkmark$ & $\checkmark$ \\
\hline & Collaboration & $\checkmark$ & $\checkmark$ & & $\checkmark$ & $\checkmark$ & $\checkmark$ \\
\hline & Problem-solving & $\checkmark$ & $\checkmark$ & $\checkmark$ & $\checkmark$ & $\checkmark$ & $\checkmark$ \\
\hline & Creativity & $\checkmark$ & $\checkmark$ & $\checkmark$ & $\checkmark$ & $\checkmark$ & $\checkmark$ \\
\hline Attitudes and values & $\begin{array}{l}\text { Democratic attitude } \\
\text { Respect }\end{array}$ & & & & & & \\
\hline
\end{tabular}

Participants had less difficulty with professional skills, STEM integration, and 21st-century skills in the second lesson plans than in the first ones. However, the second lesson plans indicated that participants still had problems with attitudes and values (Table 14)

Dudley (2011) reported that LS contributed to teachers' professional development. Participants also noted that the LSM helped them draw up better lesson plans. Research also shows that LS improves teachers' ability to develop lesson plans (Aykan, 2019; Carroll, 2013; Lyding, 2012; Mostofo, 2014). Aykan (2019) found that the LSM had positive effects on the lesson planning process. Participants remarked that LS provided them with the opportunity to develop communication and collaboration skills, which is consistent with the literature (Aykan, 2019; Dudley, 2011; Skott \& Moller, 2017; Kanauan \& Inprasitha, 2014). For example, Skot and Moller (2017) concluded that LS helped teachers communicate and collaborate more effectively. Participants believed that the LSM helped them provide better learning environments, which is consistent with the results of Marble (2007) and Pektaş (2014). The challenges of lesson planning for participants were inexperience and time management issues. Studies also report that LS has some disadvantages (Aykan \& Dursun, 2020; Demir et al., 2013).

The second question of the second subquestion addressed participants' STEM education tailored to distance learning. Their opinions were grouped under five categories: "21stcentury skills," "approaches to learning," "conceptual teaching," "cognitive skills," and "affective skills." The first category included creativity, critical thinking, collaboration, and problem-solving skills. The second category was about interdisciplinarity, learning retention, active learning, meaningful learning, and learning by doing and living. Under 
Table 15 Expert observations

\begin{tabular}{|c|c|c|}
\hline Themes & Categories & Codes \\
\hline \multirow[t]{23}{*}{ Expert observations } & \multirow[t]{11}{*}{ Professional skills } & Sharing knowledge $(n=1)$ \\
\hline & & Recognizing the shortcomings of the lesson plan \\
\hline & & Student level-appropriate \\
\hline & & Experience \\
\hline & & Detailed planning \\
\hline & & Goal-orientedness \\
\hline & & Criticizing the lesson plan $(n=2)$ \\
\hline & & Method and technical knowledge $(\mathrm{n}=2)$ \\
\hline & & Assessment and evaluation knowledge $(\mathrm{n}=2)$ \\
\hline & & Time management \\
\hline & & Positive learning environment $(n=1)$ \\
\hline & \multirow[t]{6}{*}{21 st-century skills } & Effective communication $(n=2)$ \\
\hline & & Critical thinking \\
\hline & & Empathizing $(n=2)$ \\
\hline & & Collaboration $(n=2)$ \\
\hline & & Problem-solving $(\mathrm{n}=2)$ \\
\hline & & Creativity \\
\hline & \multirow[t]{4}{*}{ Content knowledge } & Lack of engineering knowledge \\
\hline & & Lack of math knowledge \\
\hline & & Lack of technological knowledge \\
\hline & & Lack of integration \\
\hline & \multirow[t]{2}{*}{ Attitudes and values } & Hesitancy $(n=2)$ \\
\hline & & Personal criticism $(\mathrm{n}=2)$ \\
\hline
\end{tabular}

The experts' observations were grouped under four categories. The experts believed that putting lesson plans into practice had numerous benefits for participants. On the other hand, some participants were hesitant and criticized their colleagues rather than their lesson plans (Table 15)

the third category, participants talked about engineering and math concepts. The fourth category referred to transfer and raising awareness, while the fifth category involved drawing attention, developing a different perspective, self-confidence, and dispelling prejudices. Research also shows that STEM education helps students develop 21st-century skills (Karakaya, \& Avgın, 2016; Kim, 2019; Kim \& Choi, 2012; Özcan \& Koca, 2019) and acquire more knowledge, resulting in high academic performance (Çevik, 2018; Roehrig et al., 2012; Yıldırım, 2020; Yıldırım, \& Selvi, 2017). In short, our results are consistent with the literature.

The third question of the second subquestion asked participants what contributions they thought the LSM made to STEM education during distance learning. They noted that the LSM helped them acquire more pedagogical content knowledge, plan better STEM lessons, and develop 21st-century skills. Our results are significant because this is the first study to integrate an LSM with STEM education. We think that LS will make significant contributions to STEM education because it targets non-stop professional development (Aykan \& Dursun, 2020; Dudley, 2015) and high-quality lesson plans (Fernandez, 2010). In the LSM process, participants worked together to plan STEM lessons, discussed and modified their plans, and then put them into practice in their lectures. Collaboration enables teachers to 
Table 16 Experts' views of videotapes

\begin{tabular}{|c|c|c|}
\hline Themes & Categories & Codes \\
\hline & Professional skills & $\begin{array}{l}\text { Self-assessment } \\
\text { Sharing knowledge }(\mathrm{n}=1) \\
\text { recognizing the shortcomings of the lesson plan } \\
\text { Student level-appropriate } \\
\text { Sharing experience } \\
\text { Suggestion for different methods }(\mathrm{n}=2) \\
\text { Different perspective }(\mathrm{n}=2) \\
\text { Criticizing lesson plans }(\mathrm{n}=2) \\
\text { Peer-evaluation } \\
\text { Assessment and evaluation knowledge }(\mathrm{n}=2) \\
\text { Positive learning environment }(\mathrm{n}=1) \\
\text { Unfit for the goal } \\
\text { Lack of time management } \\
\text { Level-inappropriate } \\
\text { Criticizing teachers }\end{array}$ \\
\hline & 221 st-century skills & $\begin{array}{l}\text { Effective communication }(\mathrm{n}=2) \\
\text { Critical thinking } \\
\text { Social and intercultural skills }(\mathrm{n}=1) \\
\text { Collaboration }(\mathrm{n}=2) \\
\text { Problem-solving }(\mathrm{n}=2) \\
\text { Creativity }\end{array}$ \\
\hline & $\begin{array}{l}\text { Scientific process skills } \\
\text { Content knowledge }\end{array}$ & $\begin{array}{l}\text { Observation } \\
\text { Lack of engineering knowledge } \\
\text { Lack of math knowledge } \\
\text { Lack of technological knowledge } \\
\text { Lack of integration }\end{array}$ \\
\hline
\end{tabular}

The experts grouped the videotapes under four categories: Professional skills, 21st-century skills, scientific process skills, and content knowledge (Table 16)

develop professional skills and provide high-quality STEM education. Therefore, we can conclude that LS integrated with STEM education results in numerous positive learning and teaching outcomes.

The third subquestion investigated how participants thought the LSM affected the STEM lesson planning process within the scope of distance learning. They stated that the LSM made significant contributions to the lesson planning process and professional development. Numerous studies also point to the positive impact of LS on lesson planning and professional development (Aykan, 2019; Fernandez, 2010; Meiliasari, 2013; Taylor et al., 2005). However, there is no published research integrating LS with lesson planning for STEM education. Planning STEM lessons and putting them into practice is of paramount significance. We think that LSMs can help teachers draw up high-quality STEM lesson plans and equip them with professional knowledge and practical skills.

The second question of the third subquestion focused on the challenges of STEM lesson planning. Participants stated that they had a hard time managing time and had to deal with personal shortcomings (lack of knowledge and experience), and problems of teacher (being 
criticized by colleagues) and environment/condition origin (lack of material). This result is consistent with the literature (Aykan, 2019; Chen, 2017; Insprasitha et al., 2015). For example, Chassels and Melville (2009) found that preservice teachers had difficulty managing time while putting LS into practice. Lampley et al. (2018) also reported that teachers were too inexperienced in applying LS. Applying LS poses the same challenges as those of STEM lesson planning with LS.

The fourth subquestion addressed the repercussions of the LSM on professional development. The first question of the fourth subquestion looked into participants' views of the effect of the LSM on pedagogical and content knowledge. They stressed that the LSM taught them about pedagogical learning strategies and teaching and assessment-evaluation methods and improved their ability to manage the classroom, guide students, and teach effectively. Angelini and Alvarez (2018) found that LS contributed to preservice teachers' classroom management and pedagogical knowledge. Participants also remarked that putting the LSM into practice improved their content knowledge significantly. Research shows that LS improves preservice teachers' and teachers' pedagogical and content knowledge (Lamp, 2015; Alvine et al., 2007; Aykan, 2019; Barber, 2018; Copriady, 2013; Dudley, 2011; Fernandez, 2010; Kotelawala, 2012; Sims \& Walsh, 2009; Cerbin \& Kopp, 2006; Tepylo \& Moss, 2011). Therefore, our results are consistent with the literature.

The second question of the fourth subquestion concentrated on participants' views of the target skills of the LSM. They noted that the LSM helped them develop learning and innovation, life and career, and scientific process skills. Research shows that LS provides teachers with the opportunity to develop problem-solving (Isoda, 2010), creativity (González \& Deal, 2017), critical thinking (Angelini \& Alvarez, 2018), innovation (Akiba \& Wilkinson, 2016), observation (Myers, 2012), and entrepreneurship skills (Novendra \& Setiani, 2020). Our results are consistent with the literature.

The fifth subquestion addressed the effect of the LSM on STEM teaching. The first lesson plans suggested that participants had problems with professional skills, STEM integration, 21st-century skills, and attitudes and values. They focused on those weaknesses and tried to overcome them in the second lessons plans they drew up based on the LSM + STEM program. However, they still had difficulty incorporating attitudes and values into the second lesson plans or emphasizing them. Our results are consistent with the literature (Chen, 2017; Çevik, 2018; González \& Deal, 2017; Lamp, 2015). All in all, we can state that the LSM improved STEM teaching.

The sixth subquestion investigated how experts thought the LSM affected STEM education. The expert observations indicated that the LSM helped participants plan STEM lessons better, develop 21st-century skills (Skott \& Moller, 2017), acquire content knowledge (Angelini \& Alvarez, 2018; Tepylo \& Moss, 2011), and experience professional development (Chen, 2017; Dudley, 2013; Lampley et al., 2018). Research also shows that LS is instrumental in helping teachers develop 21st-century skills. For example, LS improves teachers' creativity (Lamp, 2015; González \& Deal, 2017) and collaboration (Skott \& Moller, 2017), and communication skills (Chikamori et al., 2013). The experts observed that participants were hesitant at first and criticized their colleagues rather than their lesson plans. However, the more experience they had, the more involved they became in the process (Aykan \& Dursun, 2020) and criticized the lesson plans instead of each other. The expert observations were consistent with the interview results. All in all, the results agreed with the literature.

The seventh subquestion asked participants in what way they thought the LSM helped them plan STEM lessons. The results showed that the LSM helped participants develop professional and 21st-century skills and acquire content knowledge. These results were 
consistent with the expert observations and interview results. This is the first study to address the effect of an LSM on STEM lesson planning. The results also showed that the LSM promoted professional development, resulting in quality STEM lesson plans. Lewis et al. (2012) also concluded that LS improved teachers' professional skills, making them more capable of coming up with lesson plans and putting them into practice in their lectures. Kuno (2014) and Cheng and Lee (2018) also reported that LS helped teachers develop 21st-century skills. All in all, our results agreed with the literature.

The results concerning the subquestions should be discussed in connection with each other. The results concerning the subquestions corroborate. The interview, observational, and videotape results support each other, resulting in high validity. We think that our results will contribute to the literature and pave the way for further research.

\subsection{Implications for Further Research}

The results indicated that the LSM integrated with STEM education tailored to distance learning helped teachers develop professional skills. Therefore, authorities should develop LSM-integrated long-term distance learning professional development programs for science teachers. This paper can serve as a guide to that end.

The results also showed that the LSM helped teachers develop better STEM lesson plans tailored to distance learning. Therefore, teachers should be encouraged to use LSMs and distance learning to develop high-quality lesson plans for STEM education. Distance learning can also be used to provide STEM education.

This study focused on distance learning and revealed that teachers held some negative views of distance learning. Researchers should take those views into account and design further studies accordingly. They should also focus on blended learning involving both face-to-face and distance learning.

Teachers had difficulty integrating STEM fields into their lesson plans because they had some gaps in their knowledge. Researchers should develop measurement tools to determine those gaps and provide training.

We also focused on expert opinions to better understand teachers' views and to achieve data diversification. Future studies should also employ data diversification to elicit more information on their topics of interest.

\subsection{Limitations}

This study had four limitations. First, the results are sample-specific, and therefore, cannot be generalized to the whole population. Second, participants may have expressed predominantly positive views on distance learning because they were already interested in it. Third, Participants received only $59 \mathrm{~h}$ of training on lesson planning and LSM and STEM education. Therefore, we recommend that researchers conduct long-term studies. Fourth, this study aimed to help teachers develop professional skills concerning LSM and STEM education through distance learning.

\section{Appendix 1: Teacher Interview questionnaire (TIF)}

(1) What do you think about distance learning?

(2) What do you think about the LSM for STEM education? 
(3) What do you think about STEM education?

(4) How do you think the LSM affects STEM lesson planning?

(5) How do you think the LSM affects pedagogical and content knowledge?

(6) What contributions do you think the LSM makes to STEM education?

(7) What do you think are the challenges of lesson planning?

(8) What do you think are the LSM target skills?

\section{References}

Akiba, M., \& Wilkinson, B. (2016). Adopting an international innovation for teacher professional development: State and district approaches to lesson study in Florida. Journal of Teacher Education, 67(1), 74-93. https://doi.org/10.1177/0022487115593603

Alvine, A., Judson, T. W., Schein, M., \& Yoshida, T. (2007). What graduate students (and the rest of us) can learn from lesson study. College Teaching, 55(3), 109-113. https://doi.org/10.3200/CTCH.55.3. 109-113

Angelini, M. L., \& Álvarez, N. (2018). Spreading lesson study in preservice teacher instruction. International Journal for Lesson and Learning Studies, 7(1), 23-36.

Arslan, Ö., \& Yıldırım, B. (2020). The Effect of STEM Practices on self-efficacy pedagogical and content knowledge of pre-service teachers. Inonu University Journal of the Faculty of Education, 21(3), 13391355. https://doi.org/10.17679/inuefd.789366

Aykan, A. (2019). Investigating lesson study model within the scope of professional development in terms of preservice teachers. (Unpublished doctoral dissertation). Gaziosmanpaşa University: Tokat

Aykan, A., \& Dursun, F. (2020). Lesson study model as a new implementation in professional development of teachers: perspective, advantages, limitations. Journal of Social Sciences of Mus Alparslan University, 8(6), 1683-1694. https://doi.org/10.18506/anemon.712332

Baltac1, A. (2019). The qualitative research process: how to conduct a qualitative research? Ahi Evran University Institute of Social Sciences Journal, 5(2), 368-388. https://doi.org/10.31592/aeusbed.598299

Barber, K. (2018). Developing teachers' mathematical-task knowledge and practice through lesson study. International Journal for Lesson and Learning Studies, 7(2), 136-149.

Baricaua Gutierez, S. (2016). Building a classroom-based professional learning community through lesson study: Insights from elementary school science teachers. Professional Development in Education, 42(5), 801-817.

Baxter, P., \& Jack, S. (2008). Qualitative case study methodology: Study design and implementation for novice researchers. The Qualitative Report, 13(4), 544-559.

Burns, M. (2011). Distance education for teacher training: Modes, models, and methods. Education Development Center.

Carroll, C. (2013). Exploring the impact of lesson study on the theory-practice gap in preservice teacher education. (Unpublished doctoral dissertation). University of Limerick: Ireland.

Cerbin, W., \& Kopp, B. (2006). Lesson study as a model for building pedagogical knowledge and improving teaching. International Journal of Teaching and Learning in Higher Education, 18(3), 250-257.

Çevik, M. (2018). Impacts of the project based (PBL) science, technology, engineering and mathematics (STEM) education on academic achievement and career interests of vocational high school students. Pegem Journal of Education and Instruction, 8(2), 281-306. https://doi.org/10.14527/pegegog.2018. 012

Chao, T., Saj, T., \& Tessier, F. (2006). Establishing a quality review for online courses. Educause Quarterly, 29(3), 32-39.

Chassels, C., \& Melville, W. (2009). Collaborative, reflective, and iterative Japanese lesson study in an initial teacher education program: Benefits and challenges. Canadian Journal of Education, 32(4), 734-763.

Chen, X. (2017). Theorizing Chinese lesson study from a cultural perspective. International Journal for Lesson and Learning Studies, 6(4), 283-292.

Cheng, L. P., \& Yee, L. P. (2012). A Singapore case of lesson study. The Mathematics Educator, 21(2). 34-57. Retrieved from https://files.eric.ed.gov/fulltext/EJ961515.pdf

Cheng, C. K. E., \& Lee, C. K. J. (2018). Lesson study: Curriculum management for 21st-century skills. The SAGE Handbook of School Organization. 
Chikamori, K., Ono, Y., \& Rogan, J. (2013). A lesson study approach to improving a biology lesson. African Journal of Research in Mathematics, Science and Technology Education, 17(1-2), 14-25. https:// doi.org/10.1080/10288457.2013.826967

Chong, W. H., \& Kong, C. A. (2012). Teacher collaborative learning and teacher self-efficacy: The case of lesson study. The Journal of Experimental Education, 80(3), 263-283. https://doi.org/10.1080/00220 973.2011.596854

Copriady, J. (2013). The implementation of lesson study programme for developing professionalism in teaching profession. Asian Social Science, 9(12), 176. https://doi.org/10.5539/ass.v9n12p176

Darling-Hammond, L., Hyler, M. E., \& Gardner, M. (2017). Effective teacher professional development. Palo Alto, CA: Learning Policy Institute.

De Paepe, L., Zhu, C., \& Depryck, K. (2018). Drop-out, retention, satisfaction and attainment of online learners of Dutch in adult education. International Journal on E-Learning, 17(3), 303-323.

Demir, K., Czerniak, C. M., \& Hart, L. C. (2013). Implementing Japanese lesson study in a higher education context. Journal of College Science Teaching, 42(4), 22-27.

Deneui, D., \& Dodge, T. (2006). Asynchronous learning networks and student outcomes: The utility of online learning components in hybrid courses. Journal of Instructional Psychology, 33(4), 256-259.

Dudley, P. (2011). Lesson study development in England: From school networks to national policy. International Journal for Lesson and Learning Studies, 1(1), 85-100.

Dudley, P. (2013). Teacher learning in Lesson Study: What interaction-level discourse analysis revealed about how teachers utilized imagination, tacit knowledge of teaching and fresh evidence of pupils learning, to develop practice knowledge and so enhance their pupils' learning. Teaching and Teacher Education, 34, 107-121. https://doi.org/10.1016/j.tate.2013.04.006

Dudley, P. (2015). How lesson study works and why it creates excellent learning and teaching. Routledge.

Fernandez, M. L. (2010). Investigating how and what prospective teachers learn through microteaching lesson study. Teaching and Teacher Education, 26(2), 351-562. https://doi.org/10.1016/j.tate.2009.09.012

Fujii, T. (2014). Implementing Japanese lesson study in foreign countries: Misconceptions revealed. Mathematics Teacher Education and Development, 16(1), 1-17. Retrieved from https://files.eric.ed.gov/fullt ext/EJ1046666.pdf

González, G., \& Deal, J. T. (2017). Using a creativity framework to promote teacher learning in Lesson Study. Thinking Skills and Creativity, 32, 114-128. https://doi.org/10.1016/j.tsc.2017.05.002

Horspool, A., \& Lange, C. (2012). Applying the scholarship of teaching and learning: Student perceptions, behaviors and success online and face-to-face. Assessment \& Evaluation in Higher Education, 37(1), 73-88.

Huang, R., Helgevold, N., \& Lang, J. (2021). Digital technologies, online learning and lesson study. International Journal for Lesson \& Learning Studies, 10(2), 105-117.

Inprasitha, M., Isoda, M., Yeap, B. H., \& Wang-Iverson, P. (Eds.). (2015). Lesson study: Challenges in mathematics education (Vol. 3). World Scientific.

Isoda, M. (2010). Lesson study: Problem solving approaches in mathematics education as a Japanese experience. Procedia-Social and Behavioral Sciences, 8, 17-27. https://doi.org/10.1016/j.sbspro.2010.12. 003

Jamil, F. M., Linder, S. M., \& Stegelin, D. A. (2018). Early childhood teacher beliefs about STEAM education after a professional development conference. Early Childhood Education Journal, 46(4), 409-417. https://doi.org/10.1007/s10643-017-0875-5

Kablan, Z. (2012). The Effects of level of cognitive learning and concrete experience on teacher candidates' lesson planning and application skills. Education and Science, 37(163), 239-253.

Kanauan, W., \& Inprasitha, N. (2014). Collaboration between inservice teachers and student intern in Thai lesson study. Procedia-Social and Behavioral Sciences, 116, 28-32. https://doi.org/10.1016/j.sbspro. 2014.01.163

Karakaya, F., \& Avgın, S. S. (2016). Effect of demographic features to middle school students' attitude towards STEM. Journal of Human Sciences, 13(3), 4188-4198.

Karakaya, F., Ünal, A., Cimen, O., \& Yilmaz, M. (2018). STEM awareness levels of science teachers. Journal of Research in Education and Society, 5(1), 124-138. https://doi.org/10.16949/turkbilmat.417939

Kim, G. S., \& Choi, S. Y. (2012). The Effect of creative problem-solving ability and scientific attitude through the science-based STEAM program in the elementary gifted students. Elementary Science Education, 31(2), 216-226. https://doi.org/10.15267/keses.2012.31.2.216

Kim, M. S. (2019). A systematic review of the design work of STEM teachers. Research in Science \& Technological Education. https://doi.org/10.1080/02635143.2019.1682988

Kotelawala, U. (2012). Lesson Study in a methods course: Connecting teacher education to the field. The Teacher Educator, 47(1), 67-89. https://doi.org/10.1080/08878730.2012.633840

Kuckartz, U. (2014). Qualitative text analyses: A guide to methods, practice \& using software. Sage. 
Kuno, H. (2014). Evolving the curriculum through lesson study in Japan. In P. Dudley (Ed.), Lesson study: Professional development for our time (pp. 129-144). Routledge.

Lamb, P. (2015). Peer learning between preservice teachers: Embracing lesson study. International Journal for Lesson and Learning Studies, 4(4), 343-361.

Lampley, S. A., Gardner, G. E., \& Barlow, A. T. (2018). Exploring pedagogical content knowledge of biology graduate teaching assistants through their participation in lesson study. Teaching in Higher Education, 23(4), 468-487. https://doi.org/10.1080/13562517.2017.1414786

Lewis, C. C. (2002). Lesson study: A handbook of teacher-led instructional change. Philadelphia, PA: Research for Better Schools. Retrieved from https:/www.researchgate.net/publication/246680022_ Lesson_Study_A_handbook_of_teacher-led_instructional_change

Lewis, C. (2009). What is the nature of knowledge development in lesson study? Educational Action Research, 17(1), 95-110. https://doi.org/10.1080/09650790802667477

Lewis, C., Perry, R., Foster, D., Hurd, J., \& Fisher, L. (2011). Lesson study: Beyond coaching. Educational Leadership, 69(2), 64-68.

Lewis, C. C., Perry, R. R., Friedkin, S., \& Roth, J. R. (2012). Improving teaching does improve teachers: Evidence from lesson study. Journal of Teacher Education, 63(5), 368-375. https://doi.org/10.1080/ 09650790802667477

Lyding, L. (2012). Using lesson study to help teachers design lessons with purposeful planned movement and build efficacy. (Unpublished doctoral dissertation). Arizona State University: Arizona. Retrieved from https://core.ac.uk/download/pdf/79563712.pdf

Marble, S. (2007). Inquiring into teaching: Lesson study in elementary science methods. Journal of Science Teacher Education, 18(6), 935-953. https://doi.org/10.1007/s10972-007-9071-6

Margot, K. C., \& Kettler, T. (2019). Teachers' perception of STEM integration and education: A systematic literature review. International Journal of STEM Education, 6(1), 2. https://doi.org/10.1186/ s40594-018-0151-2

Meiliasari, S. (2013). Lesson study with preservice teachers: Investigating the learning of preservice teachers in lesson study model of teaching practice course. Paper presented at Fifth International Conference on Science and Mathematics Education, Penang, Malaysia. Retrieved from https://www.resea rchgate.net/publication/270883964

Merriam, S. B. (2009). Qualitative research: a guide to design and implementation (2nd ed.). San Francisco, CA: Jossey-Bass.

Miles, M. B., Huberman, A. M., \& Saldaña, J. (2014). Qualitative data analysis: A methods sourcebook. SAGE Publications.

Mitchell, D. L. (2017). The influence of lesson study on teacher practice: A case study. (Unpublished doctoral dissertation). California State Polytechnic University: California State Polytechnic University: California. Retrieved from http://hdl.handle.net/10211.3/197395

Mostofo, J. (2014). The impact of using lesson study with preservice mathematics teachers. Journal of Instructional Research, 3, 55-63. Retrieved from https://files.eric.ed.gov/fulltext/EJ1127641.pdf

Myers, J. (2012). The effects of lesson study on classroom observations and perceptions of lesson effectiveness. Journal of Effective Teaching, 12(3), 94-104.

Norwich, B., \& Ylonen, A. (2013). Design based research to develop the teaching of pupils with moderate learning difficulties (MLD): Evaluating lesson study in terms of pupil, teacher and school outcomes. Teaching and Teacher Education, 34, 162-173. https://doi.org/10.1016/j.tate.2013.04.012

Novendra, A. M., \& Setiani, A. (2020). Application of lesson study and entrepreneurship-based learning to improve lecturer pedagogic competencies. International Journal of Advances in Social and Economics, 2(1). Retrieved from https://journal.iiesindependent.org/index.php/ijase/article/view/129

Okur Akçay, N. (2015). The adaptation of preschool teachers' attitudes and beliefs toward science teaching questionnaire into Turkish. The Journal of Academic Social Science, 3(13), 164-177.

Özcan, H., \& Koca, E. (2019). The impact of teaching the subject "pressure" with STEM approach on the academic achievements of the secondary school 7th grade students and Their Attitudes Towards STEM. Education and Science, 44(198), 201-227. https://doi.org/10.15390/EB.2019.7902

Pang, J., \& Good, R. (2000). A review of the integration of science and mathematics: Implications for further research. School Science and Mathematics, 100(2), 73-82. https://doi.org/10.1111/j.1949-8594. 2000.tb17239.x

Park, M., Dimitrov, D. M., Patterson, L. G., \& Park, D. (2017). Early childhood teachers' beliefs about readiness for teaching science, technology, engineering, and mathematics. Journal of Early Childhood Research, 15, 275-291. https://doi.org/10.1177/1476718X15614040

Parson, S. A., Hutchison, A. C., Hall, L. A., Parsons, A. W., Ives, S. T., \& Legget, A. B. (2019). U.S. teachers' perceptions of online professional development. Teaching and Teacher Education, 82, 33-42. https://doi.org/10.1016/j.tate.2019.03.006 
Patton, M. Q. (2002). Two decades of developments in qualitative inquiry: A personal, experiential perspective. Qualitative Social Work, 1(3), 261-283. https://doi.org/10.1177/1473325002001003636

Pektas, M. (2014). Effects of lesson study on science teacher candidates teaching efficacies. Educational Research and Reviews, 9(6), 164-172. https://doi.org/10.5897/ERR2013.1700

Powell, C. G., \& Bodur, Y. (2019). Teachers' perceptions of an online professional development experience: Implications for a design and implementation framework. Teaching and Teacher Education, 77, 19-30. https://doi.org/10.1016/j.tate.2018.09.004

Roehrig, G. H., Moore, T. J., Wang, H. H., \& Park, M. S. (2012). Is adding the E enough? Investigating the impact of K-12 engineering standards on the implementation of STEM integration. School Science and Mathematics, 112(1), 31-44. https://doi.org/10.1111/j.1949-8594.2011.00112.x

Sadler, T. D., Friedrichsen, P., Zangori, L., \& Ke, L. (2020). Technology-supported professional development for collaborative design of COVID-19 instructional materials. Journal of Technology and Teacher Education, 28(2), 171-177.

Saito, E., \& Atencio, M. (2013). A conceptual discussion of lesson study from a micro-political perspective: Implications for teacher development and pupil learning. Teaching and Teacher Education, 31, 87-95. https://doi.org/10.1016/j.tate.2013.01.001

Sims, L., \& Walsh, D. (2009). Lesson study with preservice teachers: Lessons from lessons. Teaching and Teacher Education, 25(5), 724-733. https://doi.org/10.1016/j.tate.2008.10.005

Sintema, E. J. (2020). Effect of COVID-19 on the performance of grade 12 students: Implications for STEM education. Eurasia Journal of Mathematics, Science and Technology Education, 16(7), 1-6. https:// doi.org/10.29333/ejmste/7893

Skott, C. K., \& Møller, H. (2017). The individual teacher in lesson study collaboration. International Journal for Lesson and Learning Studies, 6(3), 216-232.

Tan, Y. S. M. (2014). Enriching a collaborative teacher inquiry discourse: Exploring teachers' experiences of a theory-framed discourse in a Singapore case of lesson study. Educational Action Research, 22(3), 411-427. https://doi.org/10.1080/09650792.2014.880360

Taylor, A. R., Anderson, S., Meyer, K., Wagner, M. K., \& West, C. (2005). Lesson study: A professional development model for mathematics reform. The Rural Educator, 26(2). 17-22. Retrieved from https:// files.eric.ed.gov/fulltext/EJ783835.pdf

Tepylo, D. H., \& Moss, J. (2011). Examining change in teacher mathematical knowledge through lesson study. L.C. Hart, A.S. Alston, A. Murata (Ed.), Lesson study research and practice in mathematics education (pp. 59-77). Springer: Dordrecht.

Timur, B. (2012). Determination of factors affecting preschool teacher candidates' attitudes towards science teaching. Educational Sciences: Theory and Practice, 12(4), 2997-3009.

Timur, B., \& İnançlı, E. (2018). Science teacher and teacher candidates' opinions about STEM education. International Journal of Science and Education, 1(1), 48-66.

Turan, Z., Küçük, S., \& Gündoğdu, K. (2013). Use of information technology in teacher education: Current and expected status. Journal of Educational Sciences, 4(1), 1-9.

Türk, N., Kalaycı, N., \& Yamak, H. (2018). New trends in hinger education the globalizing World: STEM in teacher education. Universal Journal of Educational Research, 6(6), 1286-1304. https://doi.org/10. 13189/ujer.2018.060620

Wang, H., Moore, T. J., Roehrig, G. H., \& Park, M. S. (2011). STEM integration: Teacher perceptions and practice. Journal of Pre-College Engineering Education Research, 1(2), 1-13. https://doi.org/10.5703/ 1288284314636

Yıldırım, A., \& Şimşek, H. (2011). Qualitative research methods in social sciences. Seçkin Publications.

Yıldırım, B. (2020). MOOCs in STEM education: Teacher preparation and views. Technology, Knowledge and Learning. https://doi.org/10.1007/s10758-020-09481-3

Yıldırım, B. (2021). Preschool STEM activities: Preschool teachers' preparation and views. Early Childhood Education Journal, 49(2), 149-162. https://doi.org/10.1007/s10643-020-01056-2

Yıldırım, B., \& Selvi, M. (2017). An experimental research on effects of STEM applications and mastery learning. Journal of Theory and Practice in Education, 13(2), 183-210.

Publisher's Note Springer Nature remains neutral with regard to jurisdictional claims in published maps and institutional affiliations. 